University of Windsor

Scholarship at UWindsor

3-25-2019

\title{
Adsorption of bovine serum albumin (BSA) by bare magnetite nanoparticles with surface oxidative impurities that prevent aggregation
}

\author{
Somayeh Rahdar \\ Department of Environmental Health, Zabol University of Medical Sciences \\ Abbas Rahdar \\ Department of Physics, University of Zabol \\ Shahin Ahmadi \\ Department of Environmental Health, Zabol University of Medical Sciences \\ John F. Trant \\ Department of Chemistry and Biochemistry, University of Windsor
}

Follow this and additional works at: https://scholar.uwindsor.ca/chemistrybiochemistrypub

Part of the Biochemistry, Biophysics, and Structural Biology Commons, and the Chemistry Commons

\section{Recommended Citation}

Rahdar, Somayeh; Rahdar, Abbas; Ahmadi, Shahin; and Trant, John F.. (2019). Adsorption of bovine serum albumin (BSA) by bare magnetite nanoparticles with surface oxidative impurities that prevent aggregation. Canadian Journal of Chemistry, 97 (8), 577-583.

https://scholar.uwindsor.ca/chemistrybiochemistrypub/142

This Article is brought to you for free and open access by the Department of Chemistry and Biochemistry at Scholarship at UWindsor. It has been accepted for inclusion in Chemistry and Biochemistry Publications by an authorized administrator of Scholarship at UWindsor. For more information, please contact scholarship@uwindsor.ca. 
Notice:

This is the peer reviewed version of the following article which has been published in final form at https://doi.org/10.1139/cjc-2019-0008. 
Adsorption of bovine serum albumin (BSA) by bare magnetite nanoparticles with surface oxidative impurities that prevent aggregation

Somayeh Rahdar ${ }^{1}$, Abbas Rahdar ${ }^{2 *}$, Shahin Ahmadi ${ }^{1}$, John F. Trant ${ }^{3 *}$

${ }^{1}$ Department of Environmental Health, Zabol University of Medical Sciences, Zabol, P. O. Box. 35856-98613, Islamic Republic of Iran

${ }^{2}$ Department of Physics, University of Zabol, Zabol, P. O. Box. 35856-98613, Islamic Republic of Iran

${ }^{3}$ Department of Chemistry and Biochemistry, University of Windsor, Windsor, ON, N9B 3P4

Canada

* Corresponding Authors

Email addresses: a.rahdar@uoz.ac.ir; j.trant@uwindsor.ca

Corresponding author for the editorial office:

Dr. John F. Trant

Fax Number: 1-519-973-7098

Phone number: 1-519-253-3000 extension 3528. 


\begin{abstract}
Bare, uncoated magnetite nanoparticles, synthesized using an electrochemical surfactantfree synthesis, have highly oxidized surfaces that prevent aggregation. These particles have demonstrated highly intriguing biological activity showing extremely potent antibiotic activity against both gram-positive and gram-negative bacteria with little toxicity to rats. This difference in activity could be ascribed to the nature of the protein corona. In this study the kinetics and thermodynamics of the binding of bovine serum albumin, used as a model serum protein, to these magnetite nanoparticles was analyzed. There is no significant change in particle diameter by dynamic light scattering following adsorption indicating corona formation does not induce aggregation. The maximum adsorption capacity of the particles was determined to be $300 \mathrm{mg}$ of $\mathrm{BSA} / \mathrm{g}$ of magnetite. The particles are able to adsorb $90 \%$ of the BSA at protein concentrations as high as $500 \mathrm{mg} / \mathrm{L}$. The adsorption is best described using a pseudo-second-order model and a Langmuir Type III isotherm model. Thermodynamic analysis showed that the process is entropically driven and is spontaneous at all tested temperatures and conditions. However, it appears to be a weak to moderate physical adsorption. This moderate binding affinity could indicate the differential biological activity of these particles towards bacteria and mammalian cells and further support the contention that these are potentially useful new tools for targeting antibiotic-resistant bacteria.
\end{abstract}

Keywords: Magnetite nanoparticles, bovine serum albumin, Langmuir isotherm, adsorption kinetics, adsorption thermodynamics 


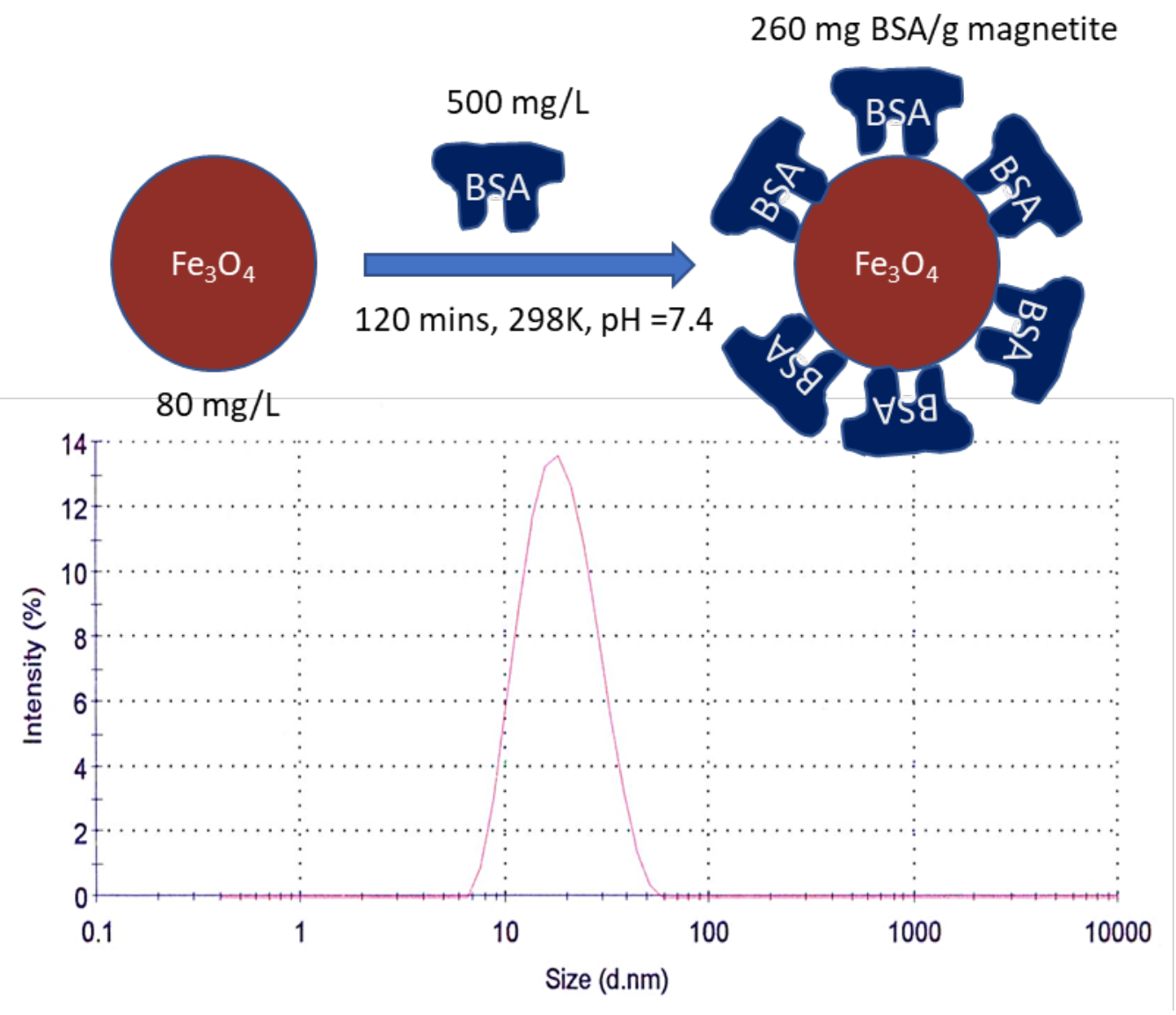




\section{Introduction}

Albumin is the most abundant protein in circulating mammalian blood and is the primary component responsible for serum-protein adsorption of drugs, fatty acids, anions, metal ions, antioxidants and other circulating small molecules and nanoparticles. ${ }^{1,2}$ The model animal albumin is bovine serum albumin (BSA) due to its ubiquitous availability, low cost, and common use which allows for the easy standardization of results between different research teams. ${ }^{3}$ BSA is a globular protein with a prelate spheroid-like shape (dimensions of $4 \mathrm{~nm} \times 4 \mathrm{~nm} \times 14 \mathrm{~nm}$ ) with an overall negative surface charge of -18 at physiological $\mathrm{pH} .{ }^{4}$ The adsorption of small molecules onto BSA can be responsible for the bioavailability of the drug, but similarly, understanding the adsorption of BSA onto nanoparticles is essential for the biological activity of these nanoparticles as they rapidly form a protein corona. ${ }^{5-8}$

Underlying the general rule that nanoparticles rapidly develop a protein coating are the specifics involved in the binding of any given protein to any given nanoparticle surface including the electrostatic compatibility of the surfaces, the steric demands of the protein, the overall charge and charge distribution on the protein, and environmental factors including $\mathrm{pH}$, ionic strength and initial protein concentration. ${ }^{9-11}$

The literature contains many reports that have explored protein adsorption, generally BSA, onto various nanoparticle surfaces such as gold nanoparticles, ${ }^{12}$ hydroxyapatite, ${ }^{11}$ organic polymers, ${ }^{13}$ silica, graphene, ${ }^{14}$ titanium oxide, ${ }^{15}$ bio-ceramic nanoparticles, ${ }^{8}$ and magnetite. ${ }^{16-18}$ Many of these latter systems are better described as forming a protein shell around a magnetite cores, as magnetic nanoparticles continue to promise to emerge as useful tools in biotechnology, separation sciences, and biomedicine due to their supermagnetism, good magnetic saturation and coercivity, and their relative biocompatibility and environmental benign nature compared to other inorganic nanoparticle systems. ${ }^{19-21}$ Consequently, many different methods have been applied to the study of BSA-magnetite dynamics and thermodynamics to both better delineate the effect of conditions on protein adsorption on magnetite surfaces, and act as a validation of the new techniques. These have included Van't Hoof analysis, ${ }^{16}$ response surface methodology using vibrating-sampling magnetometry and differential scanning calorimetry, ${ }^{13}$ the application of a linear driving force mass transfer model using the mass balance of the samples, ${ }^{18}$ Raman spectroscopy and circular dichroism, ${ }^{22}$ and the use of commercial protein quantification kits. ${ }^{23}$

These results are united in their conclusions that $\mathrm{pH}$, temperature, and initial protein concentration dominate the binding effects, and these can also influence the degree of protein denaturation at the air-water interface, ${ }^{24}$ although this hasn't been studied on a magnetite surface. There is a single report studying thermal denaturation of BSA-magnetite at very high temperatures but no comments were made as to the denaturation of the BSA prior to pyrolysis. ${ }^{25}$ In the extant magnetite examples, the absorption of the BSA has either been focused on creating a $\mathrm{Fe}_{3} \mathrm{O}_{4} @ \mathrm{BSA}$ core-shell system for further applications, ${ }^{13,17,26}$ or studying the absorption of BSA onto an already coated magnetite particle. . $^{9} 14,16,27$ This is mainly because uncoated magnetite nanoparticles readily aggregate and have little application and so are hard to isolate, process and study. However, we have recently reported on a green organic solvent and surfactant-free electrochemical synthesis of magnetite nanoparticles that results in a surface containing highly-oxidized species. ${ }^{28,29}$ These are highly resistant to aggregation and show potent antimicrobial activity. ${ }^{30}$ These systems lack potentially toxic surfactants and have potential for biological applications. ${ }^{31-33}$ For example, our recent study showed that these iron oxide nanoparticles showed potent antimicrobial activity, effective at the same mass concentrations as ampicillin and chloramphenicol against both $S$. aureus 
and E. coli. The mechanism of action was attributed to be oxidative stress caused by the highly reactive Fe-O-O-H groups on the surface that resulted from our synthesis. This was slightly surprising as, in any biological experiment, we would expect these nanoparticles to be rapidly fouled by a protein corona. In order to better understand this process, we have carried out the current study looking at BSA adsorption onto our nanoparticles as a function of initial protein concentration, temperature, and the rate of dosing. This data is then interpreted using Freundlich and Langmuir isotherms to better understand the process, and the binding data as a function of temperature was then used determine the activation energy $\left(\mathrm{E}_{\mathrm{a}}\right)$, enthalpy $\left(\Delta \mathrm{H}^{\mathrm{o}}\right)$, entropy $\left(\Delta \mathrm{S}^{\mathrm{o}}\right)$, and free energy $\left(\Delta \mathrm{G}^{\mathrm{o}}\right)$ values of this process.

\section{Experimental Details}

\subsection{Materials}

Bovine serum albumin (BSA; MW $67 \mathrm{kDa}$ ) was purchased from Sigma Millipore. All other chemicals used in this study besides study were purchased from Merck Co. (Germany).

\subsection{Synthesis method of nanoparticles}

The $23 \mathrm{~nm}$ magnetite nanoparticles were synthesized using our previously published method. ${ }^{30}$

\subsection{Nanoparticle characterization}

X-ray diffraction (XRD) of nanoparticles was carried out using a D8 Advance X'Pert X-Ray diffractometer (Bruker, the diffractometer from Philips and a $\mathrm{CuK} \alpha$ radiation source, Figure S1). The magnetic behaviour of the samples was studied using vibrating sample magnetometry (VSM, Kavir Precise Magnetic, Iran, Figure S3). Field emission scanning electron microscopy (FE-SEM, Mira 3-XMU instrument capable of 700,000x magnification) was used to study the morphology of the nanoparticles (Figure S2). Fourier-transform infrared spectroscopy was done using a JASCO 640 plus machine ( $4000-400 \mathrm{~cm}^{-1}$ ) at room temperature using $\mathrm{KBr}$ pellets. The size distribution of the nanoparticles was obtained using dynamic light scattering (DLS) on a Zetasizer Nano ZS (Malvern Instruments, UK) equipped with a He-Ne laser source $(633 \mathrm{~nm})$ with vertically polarized light.

\subsection{Bovine serum albumin Solution and analysis}

The BSA stock solution was prepared by dissolving bovine serum albumin in deionized water (corrected to $\mathrm{pH}=7.4$ ). The required concentrations of BSA for the studies were then obtained by serial dilutions of this stock solution. The amount of BSA adsorbed was calculated by subtracting the amount present in the supernatant solution after treatment from the amount of protein present before the addition of the $\mathrm{Fe}_{3} \mathrm{O}_{4}$ nanoparticle using the intensity of the UV absorption at $280 \mathrm{~nm}$ employing a standard curve as per the methodology of Peng and co-workers (Figure S4). ${ }^{18}$

\subsection{Batch Adsorption Experiments}

The experiments were performed discontinuously in $100 \mathrm{ml}$ flasks containing $50 \mathrm{ml}$ of solution on a shaker oscillating at $150 \mathrm{rpm}$. The experiments were performed considering four variables: absorbent (nanoparticle) dosage $(0.02,0.03,0.04,0.05,0.08$ and $0.1 \mathrm{~g} / \mathrm{l})$, contact time $(60,120$, $240,300 \mathrm{~min})$, initial concentration of BSA $(100,200,400,500 \mathrm{mg} / \mathrm{l})$, and temperature $(25,35$, $\left.45^{\circ} \mathrm{C}\right)$. 
The amount of absorbed BSA per unit weight of $\mathrm{Fe}_{3} \mathrm{O}_{4}$ nanoparticle at time $\mathrm{t}, \mathrm{q}_{\mathrm{e}}(\mathrm{mg} / \mathrm{g})$, was calculated using the following equation:

$q_{e}=\frac{\left(C_{0}-C_{t}\right) V}{M}$

Where, $\mathrm{C}_{0}$ and $\mathrm{C}_{\mathrm{t}}$ are the BSA concentrations at time zero and $\mathrm{t}(\mathrm{mg} / \mathrm{l})$ respectively, $\mathrm{V}$ is the volume of the solution $(\mathrm{L})$, and $\mathrm{M}$ is the mass of nanoparticles $(\mathrm{g})$.

To express the percent of BSA removal, the following equation was used:

$\%=\frac{\left(C_{0}-C_{f}\right)}{C_{0}} \times 100 \%$

where $\mathrm{C}_{0}$ and $\mathrm{C}_{\mathrm{f}}$ represent the initial and final BSA concentrations. All tests were performed in duplicate to insure the reproducibility of the results; the mean of the two measurements is reported as per Ayranci and Duman. ${ }^{34}$ In cases where the values differed by more than $0.5 \%$, additional runs were carried out.

\section{Results and discussion}

\subsection{Characterization of the nanoparticles}

The Iron Oxide nanoparticles were previously characterized using XRD, SEM, and VSM techniques by our group. ${ }^{29,}{ }^{30}$ For the current study, the average crystallite size of the magnetite nanoparticles was $23 \mathrm{~nm}$ according to the (3 111 ) plane reflection from the XRD pattern that was extracted using the Scherer formula. A nearly spherical morphology of the Iron Oxide nanoparticles was confirmed by FE-SEM.

\subsection{FT-IR studies}

Fourier-transform infrared spectroscopy of iron oxide nanoparticles was conducted both before and after adsorption of BSA, and the spectra are provided as Figure 1.

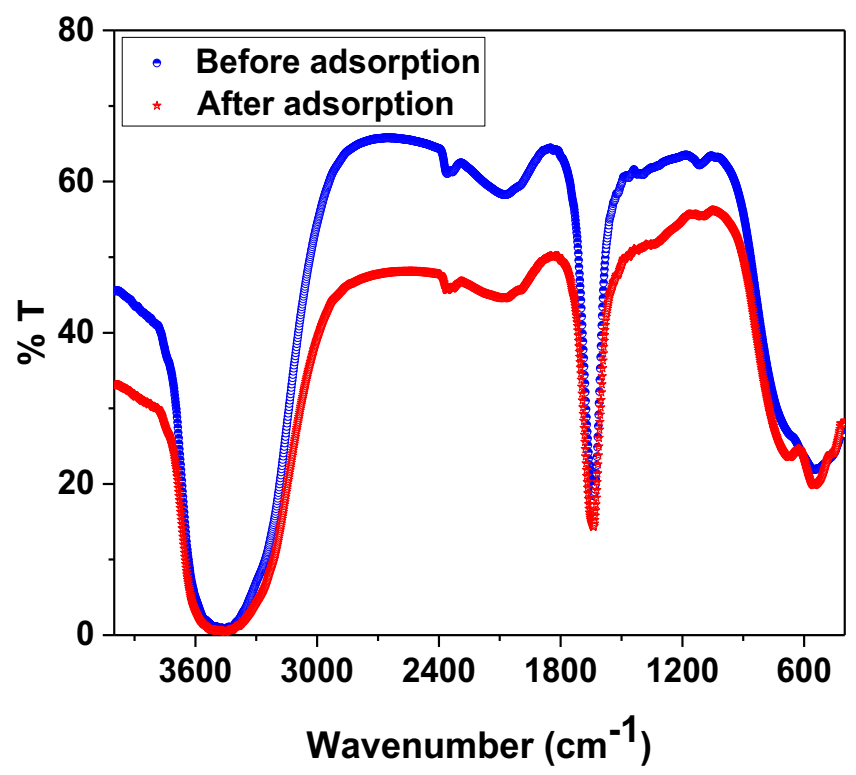


Figure 1. FT-IR spectrum of $\mathrm{Fe}_{3} \mathrm{O}_{4}$ nanoparticles both before and after the absorption experiment.

The FT-IR spectrum does not change markedly and is dominated by the absorption bands associated with $\mathrm{Fe}_{3} \mathrm{O}_{4}, 3400$ and $1618 \mathrm{~cm}^{-1}$ corresponding to $\mathrm{OH}$ stretching vibration and $\mathrm{O}-\mathrm{H}$ bending vibration, and $576 \mathrm{~cm}^{-1}$ corresponding to the Fe-O stretching vibration. ${ }^{26}$ The presence of the BSA cannot be confirmed by FT-IR analysis: although transmittance decreases, there is no clear shift in the spectral maxima. The spectrum of BSA is dominated by carbonyl stretching between $1515 \mathrm{~cm}^{-1}$ and $1660 \mathrm{~cm}^{-1}$ and $\mathrm{O}-\mathrm{H}$ and N-H stretches above $3000 \mathrm{~cm}^{-1}$. These signals overlap with those of the magnetite. A slight shoulder on the high-energy side of the carbonyl peak is consistent with BSA, but this is not clear enough to be definitive for characterization purposes.

\subsection{Dynamic light scattering (DLS) measurements}

DLS is an effective tool to characterize dynamic parameters of NPs including the diffusion coefficient and particle size within a colloidal system. The time-dependent scattered light intensity from a nano-colloidal solution is a fluctuating quantity that depends on the size, Brownian motion and diffusive behaviour of NPs in solution and the viscosity of the continuous phase, water in this case. ${ }^{35,36}$ The DLS intensity spectrographs of the nanoparticles, both before and after treatment, are provided as Figure 2 for adsorption in the presence of $200 \mathrm{mg} / \mathrm{L}$ of BSA. The data indicates a moderate, but meaningful increase in size with the addition of the protein from about $20 \mathrm{~nm}$ (in the absence of BSA) to $29 \mathrm{~nm}$ (in the presence of BSA) which is consistent with the expected monolayer (based on the ratio of surface area to adsorbed BSA, and the hydrodynamic dimensions of BSA) ${ }^{37}$.

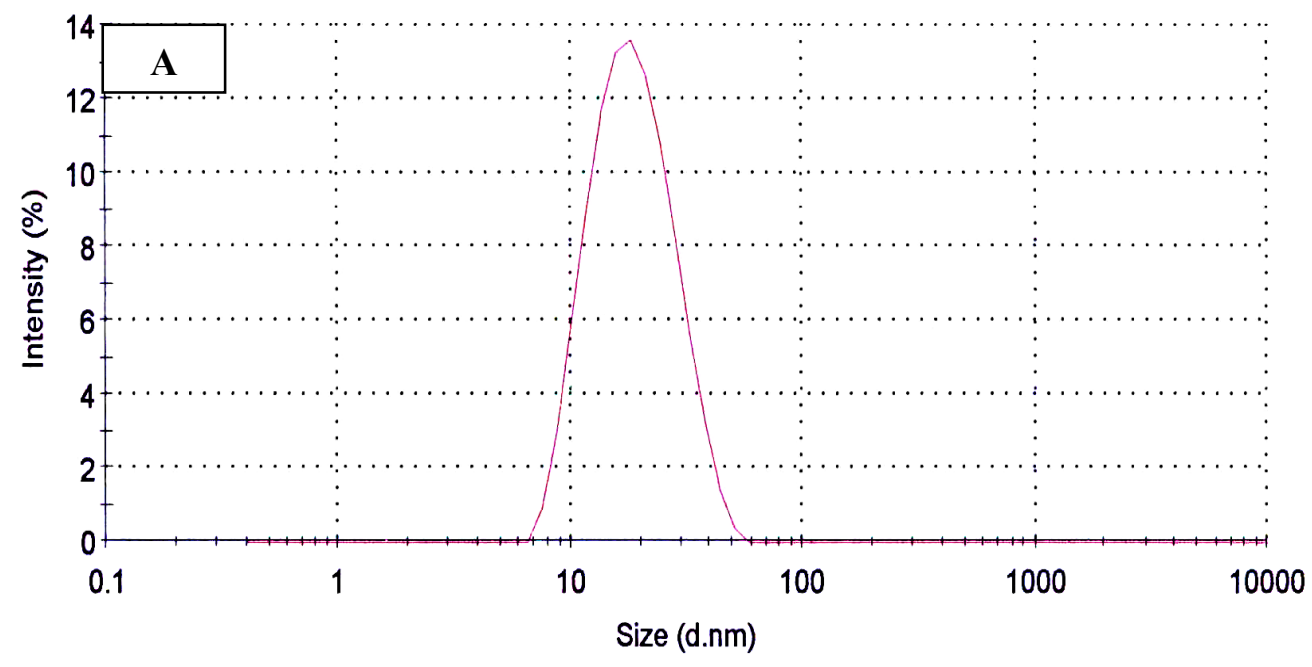




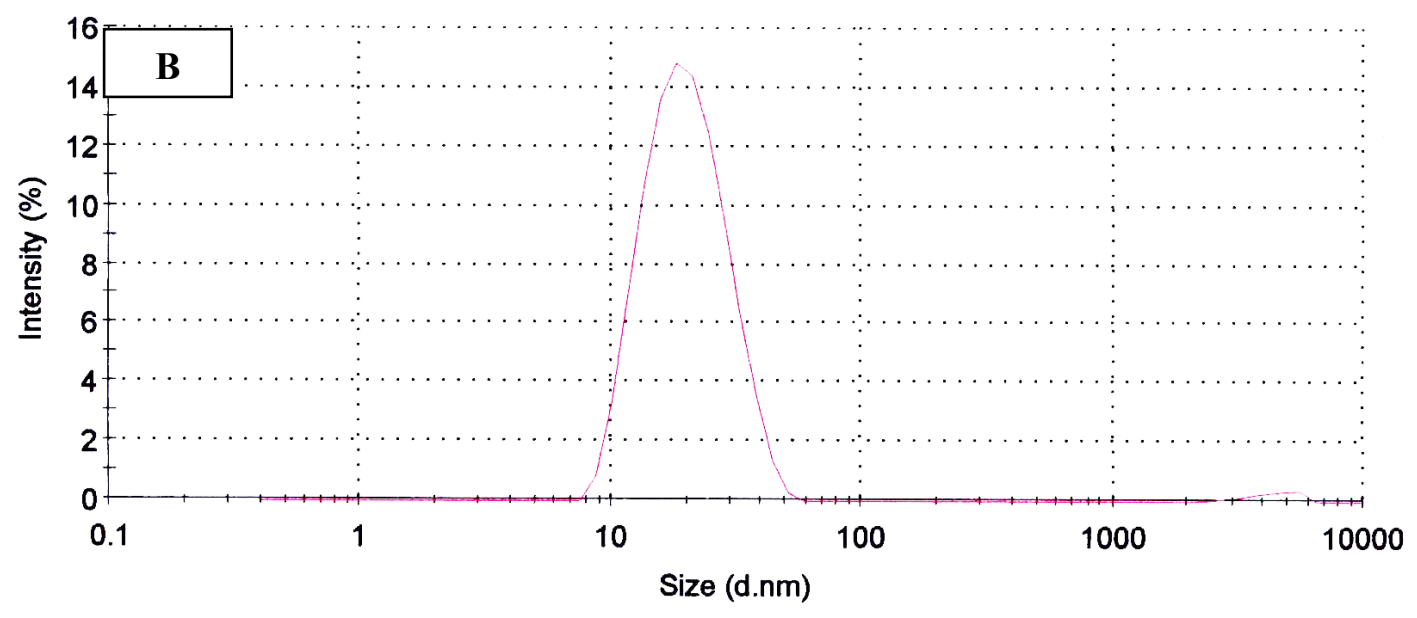

Figure 2. The size distribution of the iron oxide nanoparticles (adsorbent dosage $0.08 \mathrm{~g} / \mathrm{L}$ ) as determined by DLS intensity measurements, both before (A) and after (B) adsorption of BSA (200 $\mathrm{mg} / \mathrm{mL}, 120 \mathrm{~min}$ incubation).

3.4. Protein adsorption study. Three parameters are essential for determining the binding isotherms: temperature, $\mathrm{pH}$, and concentration of adsorbent. We determined that physiological $\mathrm{pH}$ (7.4), and ambient temperature $(298 \mathrm{~K})$ were reasonable selections for the first two parameters. We then determined what concentration of magnetite would absorb a substantial percentage of a BSA solution.

3.4.1. Effect of adsorbent dose: The effect of the adsorbent dosage level on the removal of BSA was studied by varying the nanoparticle content from 0.02 to $0.1 \mathrm{~g} / \mathrm{L}$ while holding the $\mathrm{pH}$ constant at 7.4, the initial BSA concentration at $200 \mathrm{mg} / \mathrm{L}$, the temperature at $298 \mathrm{~K}$, and the contact time constant at 120 min (Figure 3). 


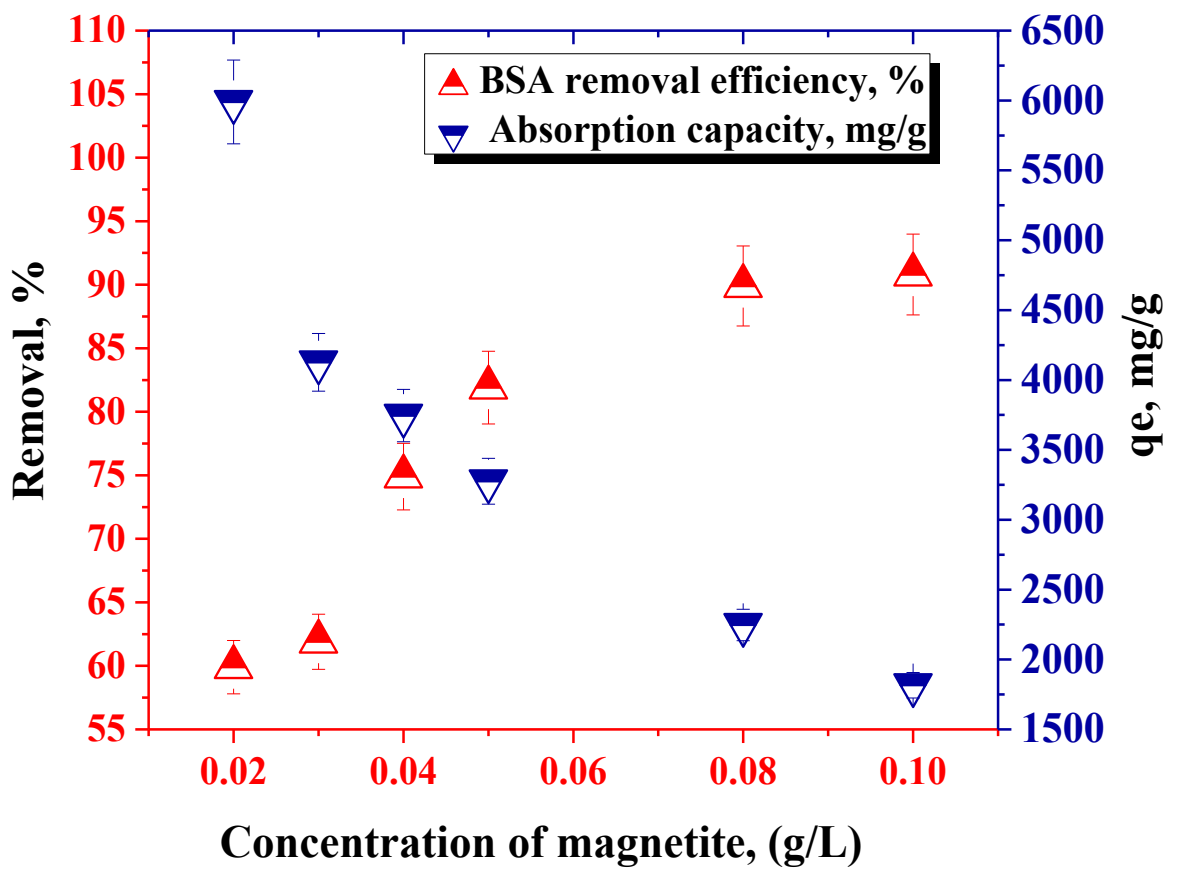

Figure 3. Percent removal and adsorption capacity of BSA (using a $200 \mathrm{mg} / \mathrm{L}$ solution) as a function of nanoparticle concentration (absorbent dose) after 120 minutes of co-incubation.

When the adsorbent concentration increased from 20 to $100 \mathrm{mg} / \mathrm{L}$ at $200 \mathrm{mg} / \mathrm{L}$ of BSA, the proteinbinding efficiency increased from $59.9 \%$ to $90.5 \%$. However, as expected, the adsorption capacity $\left(q_{e}\right)$ of the $\mathrm{Fe}_{3} \mathrm{O}_{4} \mathrm{NPs}$ decreased from 5990 to $1816 \mathrm{mg} / \mathrm{g}$. The maximum BSA adsorption is largely reached at a concentration of $0.8 \mathrm{~g} / \mathrm{L}$ of magnetite nanoparticles, further increasing the amount of magnetite has little effect. BSA-adsorption efficiency falls as the dose increases. At very low concentrations, the surface of the particle appears supersaturated $(0.02 \mathrm{~g} / \mathrm{L})$, but at $0.03 \mathrm{~g} / \mathrm{L}$ and above, $\mathrm{q}_{\mathrm{e}}$ forms a linear relationship with dosage which is consistent with a not fully saturated system, although the reason for the maximum adsorption being $90 \%$ requires further exploration although it might be due to segregation of some of the protein as nanoaggregates. A similar result was previously reported by Kopac and Bozgeyik. ${ }^{38}$ This high qe is much greater than that reported for other materials, i.e. $44.4 \mathrm{mg} / \mathrm{g}$ for $\mathrm{TiO}_{2},{ }^{38}$ and $30 \mathrm{mg} / \mathrm{g}$ for hydroxyapatite particles, ${ }^{11}$ and 200 $\mathrm{mg} / \mathrm{g}$ for gold. ${ }^{39}$ This exceptional value suggests that a very significant protein corona is formed around the nanoparticle that must involve multilayers of BSA forming around the particle core.

3.4.2. Effect of contact time and initial BSA concentration: The contact time and adsorbate concentration are recognized as important parameters in for determining the kinetics and thermodynamics of the absorption process. The effect of contact time on the degree of adsorption of BSA onto magnetite NPs is shown in Figure 4. 

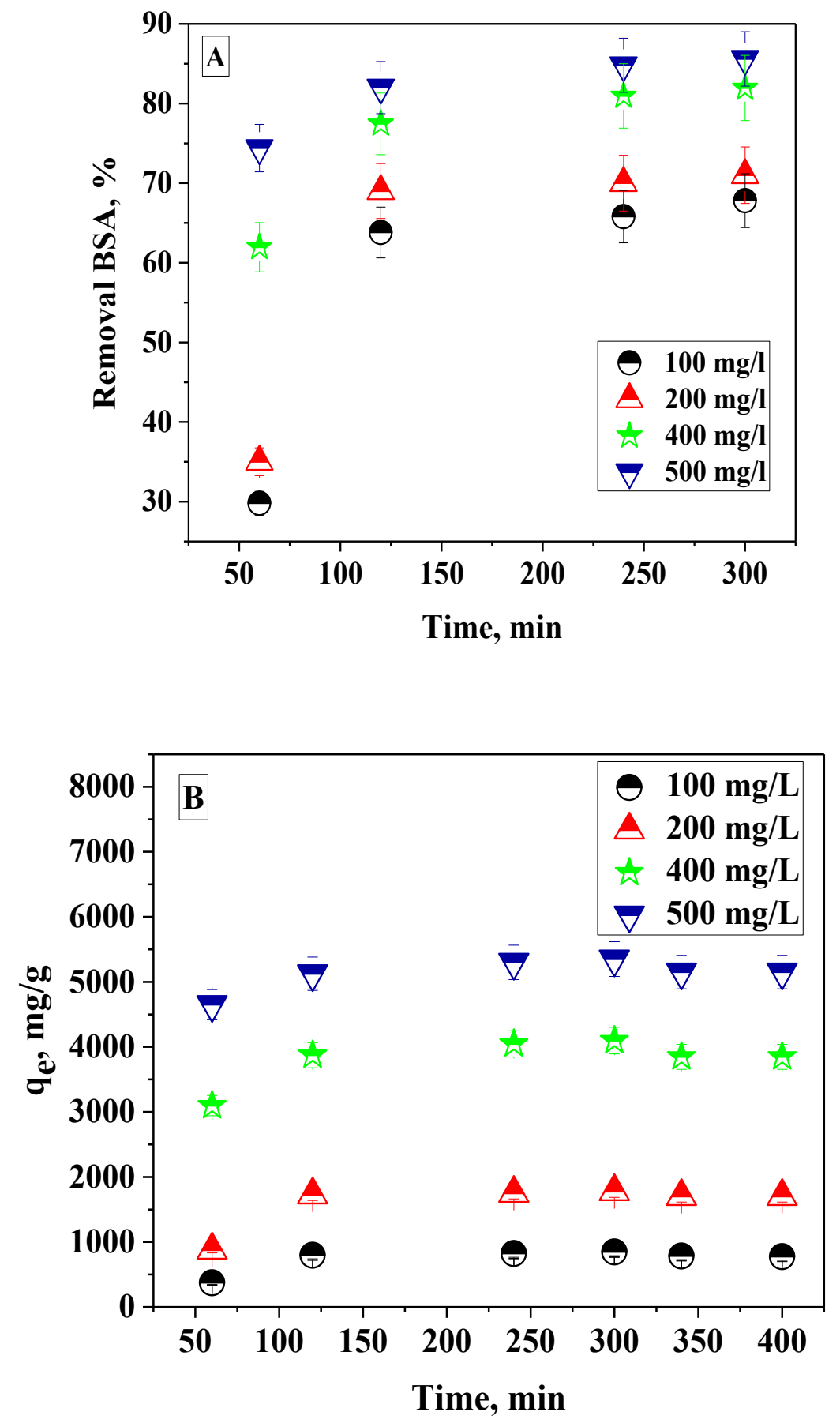

Figure 4. A) Percent sequestration of $\mathrm{BSA}$ onto $\mathrm{Fe}_{3} \mathrm{O}_{4} \mathrm{NPs}$ at an as a function of time and concentration of BSA; B) Binding efficiency of the NPs as a function of time and concentration of BSA. All measurements acquired using a nanoparticle concentration of $0.08 \mathrm{gL}^{-1}, \mathrm{~T}=298 \mathrm{~K}$, and $\mathrm{pH}=7.4$. 
BSA absorption is not an instantaneous process, although the protein does rapidly adsorb to the surface over the first two hours in the first $120 \mathrm{~min}$ (63-83\% after two hours, Figure 4A, Table S2). The rate is dependent on the initial concentration of BSA; counterintuitively, the higher the concentration, the higher the percentage of BSA that is absorbed. This would be consistent with an adsorption model that suggests weak BSA binding to the nanoparticle, but strong BSA-BSA binding indicating the formation of layers of protein on the particle. Regardless of the final percent removed, the BSA reaches equilibrium after about 120 min with only slight increases observed over the following 3 hours. Clearly over time the absorption efficiency diminishes due to a saturation of absorption sites. Curiously these magnetic nanoparticles absorb a greater amount of BSA than previously reported non-magnetic samples of similar diameter. ${ }^{40}$

The maximum BSA adsorption was achieved after $120 \mathrm{~min}$. Therefore, the $120 \mathrm{~min}$ period was chosen as the optimum contact time for all further measurements. Counterintuitively, the percent removal of the BSA increases as a function of the initial concentration of BSA - the more BSA that is present, the higher percentage is removed. This might be due to the favourable surface interactions and the entropic and enthalpic favourability of the adsorption processes (see below). This is dramatically illustrated by Figure $4 \mathrm{~B}$ which shows a dramatic increase in adsorption efficiency as the BSA concentration increases.

3.4.3 Analysis of Adsorption Isotherm: The relationship between the amount of BSA concentration adsorbed onto the $\mathrm{Fe}_{3} \mathrm{O}_{4}$ NPs surface and the remaining BSA concentration in the aqueous phase at equilibrium can be examined using an adsorption equilibrium isotherm analysis. Adsorption isotherm plots indicate whether the adsorption phenomenon can be modelled using Langmuir isotherms. This model implies that adsorption occurs in a monolayer until all surface active sites are saturated. Then additional layers can form. The adsorption isotherms were investigated using both the Langmuir and Freundlich models. ${ }^{41-43}$

Table 1. The isotherm equations used in the study.

\begin{tabular}{|c|c|c|}
\hline Isotherm model & Linear expression & Plot \\
\hline \multirow[t]{2}{*}{ Freundlich } & $\log q_{e}=\frac{1}{n} \log C_{e}+\log k_{f}$ & $\mathrm{Inq}_{\mathrm{e}}$ vs InC $\mathrm{C}_{\mathrm{e}}$ \\
\hline & $\begin{array}{l}\text { Type(I): } \frac{C_{e}}{q_{e}}=\frac{1}{q_{m}} \cdot \frac{1}{k_{1}}+\frac{C_{e}}{q_{m}} \\
\text { Type(II): } \frac{1}{q_{\rho}}=\frac{1}{a_{m}}+\left(\frac{1}{q_{m} K}\right) \frac{1}{C_{\rho}}\end{array}$ & $\left(\mathrm{C}_{\mathrm{e}} / \mathrm{q}_{\mathrm{e}}\right)$ vs $\mathrm{C}_{\mathrm{e}}$ \\
\hline \multirow[t]{2}{*}{ Langmuir } & Type(III): $q_{e}=q_{m}-\left(\frac{1}{K_{L}}\right) \frac{q_{e}}{C_{e}}$ & 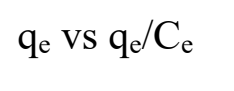 \\
\hline & Type(IV): $\frac{q_{e}}{c_{e}}=K_{L} q_{m}-K_{L} q_{e}$ & $\mathrm{q}_{\mathrm{e}} / \mathrm{C}_{\mathrm{e}} \mathrm{vs} \mathrm{q}_{\mathrm{e}}$ \\
\hline
\end{tabular}




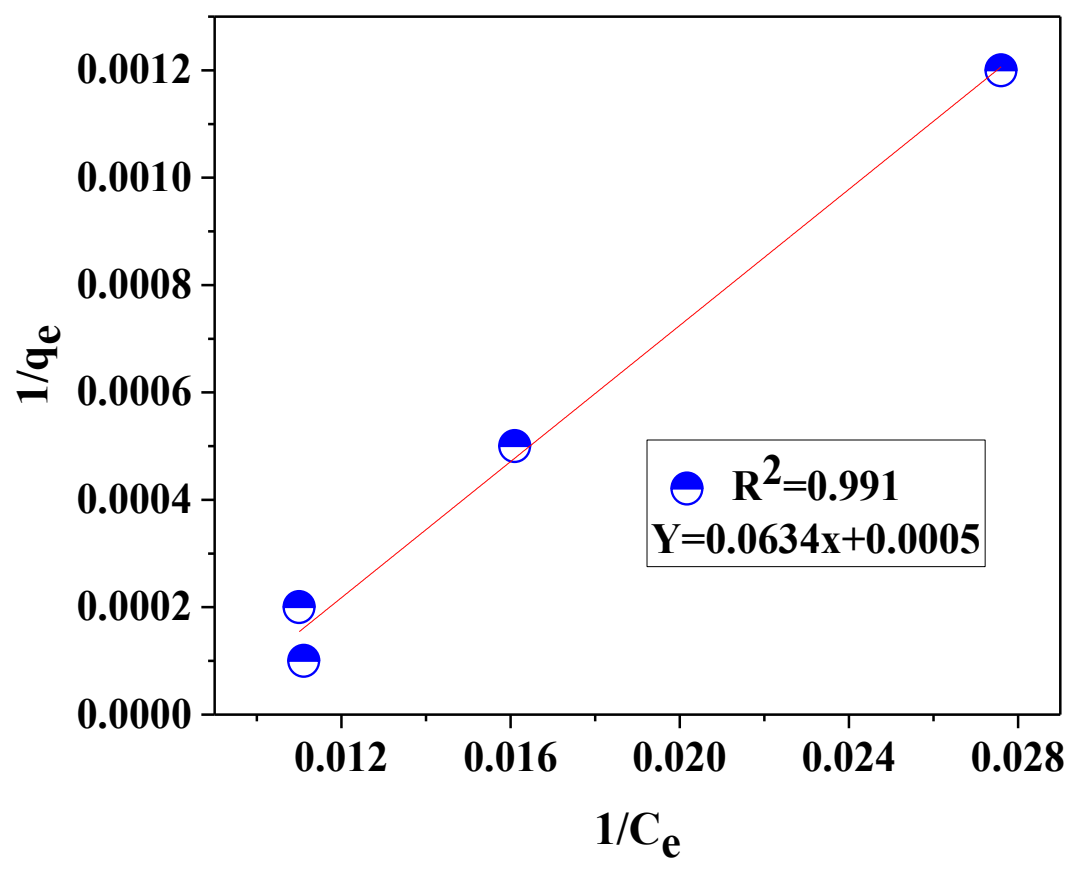

Figure 5. Graphical representation of the Langmuir Type (II) model of the binding of BSA onto $\mathrm{Fe}_{3} \mathrm{O}_{4} \mathrm{NPs}$ at adsorbent dosage $0.08 \mathrm{~g} / \mathrm{L}, \mathrm{T}=298 \mathrm{~K}, \mathrm{pH}=7.4$, and time $=120 \mathrm{~min}$.

The experimental data is most consistent with the Langmuir Type (II) isotherm (Figure 5). This conclusion was reached based on a comparison of the correlation coefficients, $\mathrm{R}^{2}$ (Table 2 ). The main characteristic of any Langmuir isotherm is the dimensionless equilibrium parameter $\left(\mathrm{R}_{\mathrm{L}}\right)$ constant, which is defined by the following relation ${ }^{18}$ :

$R_{L}=\frac{1}{1+\mathrm{bC}_{0}} \mathrm{Eq}(3)$

$\mathrm{C}_{0}$ represents the $\mathrm{BSA}$ concentration, $500 \mathrm{mg} / \mathrm{L}$. The value of $\mathrm{R}_{\mathrm{L}}$ defines the type of isotherm. For a desirable absorption $0<\mathrm{R}_{\mathrm{L}}<1$; for undesirable absorption $\mathrm{R}_{\mathrm{L}}>1$, for linear absorption $\mathrm{R}_{\mathrm{L}}=1$, and for reversible absorption $\mathrm{R}_{\mathrm{L}}=0$. The $\mathrm{R}_{\mathrm{L}}$ values in this study were calculated to be 0.166 , and suggest that BSA adsorption is desirable. The Langmuir Type (II) isotherm model means that adsorption increases exponentially as pressure increases. This is naturally consistent with a model where strong adsorbent-adsorbent interactions are present. As BSA binds to the nanoparticle, additional BSA molecules can more readily bind. This observation is completely consistent with our earlier observation that percentage removal of BSA increases as initial BSA solution concentration increases and that the $\mathrm{q}_{\mathrm{e}}$ values are exceptionally high for this system.

Table 2. Isotherms parameters obtained by linear regression method for the sorption of BSA by $\mathrm{Fe}_{3} \mathrm{O}_{4}$ NPs. BSA concentration 100-500 mg/L, adsorbent dosage $0.08 \mathrm{~g} / \mathrm{L}$, temperature $298 \mathrm{~K}, \mathrm{pH}$ 7.4 , experiments run for $120 \mathrm{~min}$. 


\begin{tabular}{|c|c|c|c|}
\hline \multicolumn{2}{|l|}{ Isotherms } & \multirow{2}{*}{$\frac{\mathbf{R}^{2}}{0.909}$} & \multirow{2}{*}{$\begin{array}{l}\text { parameters } \\
\mathrm{K}_{\mathrm{F}}=14.42 \mathrm{mg} / \mathrm{g} \\
1 / \mathrm{n}=1.587 \mathrm{~L} / \mathrm{mg}\end{array}$} \\
\hline Freundlich & & & \\
\hline \multirow[t]{4}{*}{ Langmuir } & Type(I) & 0.954 & $\begin{array}{l}\mathrm{q}_{\mathrm{m}}=15.79 \mathrm{mg} / \mathrm{g} \\
\mathrm{K}_{\mathrm{L}}=134.14 \mathrm{~L} / \mathrm{mg}\end{array}$ \\
\hline & Type(II) & 0.991 & $\begin{array}{l}\mathrm{q}_{\mathrm{m}}=1842.18 \mathrm{mg} / \mathrm{g} \\
\mathrm{K}_{\mathrm{L}}=0.01 \mathrm{~L} / \mathrm{mg}\end{array}$ \\
\hline & Type(III) & 0.986 & $\begin{array}{l}\mathrm{q}_{\mathrm{m}}=0.0001 \mathrm{mg} / \mathrm{g} \\
\mathrm{K}_{\mathrm{L}}=14.36 \mathrm{~L} / \mathrm{mg}\end{array}$ \\
\hline & Type(IV) & 0.986 & $\begin{array}{l}\mathrm{q}_{\mathrm{m}}=0.07 \mathrm{mg} / \mathrm{g} \\
\mathrm{K}_{\mathrm{L}}=1856.19 \mathrm{~L} / \mathrm{mg}\end{array}$ \\
\hline
\end{tabular}

3.4.4. Adsorption kinetics: The adsorption kinetics of $\mathrm{BSA}$ on the $\mathrm{Fe}_{3} \mathrm{O}_{4} \mathrm{NPs}$ were examined at $\mathrm{pH} 7.4$ for the different initial concentrations of BSA using both pseudo-first-order and pseudosecond-order models (Figure 6).

$$
\begin{array}{ll}
\log \left(\mathrm{q}_{\mathrm{e}}-\mathrm{q}_{\mathrm{t}}\right)=\log \mathrm{q}_{\mathrm{e}}-\frac{\mathrm{K}_{1} \mathrm{t}}{2.303} & E q(4) \\
\frac{t}{q_{t}}=\frac{1}{K_{2} q_{e}^{2}}+\frac{t}{q_{e}} & \mathrm{Eq}(5)
\end{array}
$$

where $\mathrm{k}_{2}$ is the pseudo-second-order rate constant $(\mathrm{g} / \mathrm{mg} / \mathrm{min}), \mathrm{k}_{1}$ is the pseudo first order rate constant $(\mathrm{g} / \mathrm{mg} / \mathrm{min}) \mathrm{q}_{\mathrm{e}}$ the quantity of BSA adsorbed at equilibrium $\left(\mathrm{mg} . \mathrm{g}^{-1}\right)$; $\mathrm{q}_{\mathrm{t}}$ the quantity of BSA adsorbed at time $t\left(\mathrm{mg} \cdot \mathrm{g}^{-1}\right)$ and $\mathrm{t}$ is the time $(\mathrm{min})$.

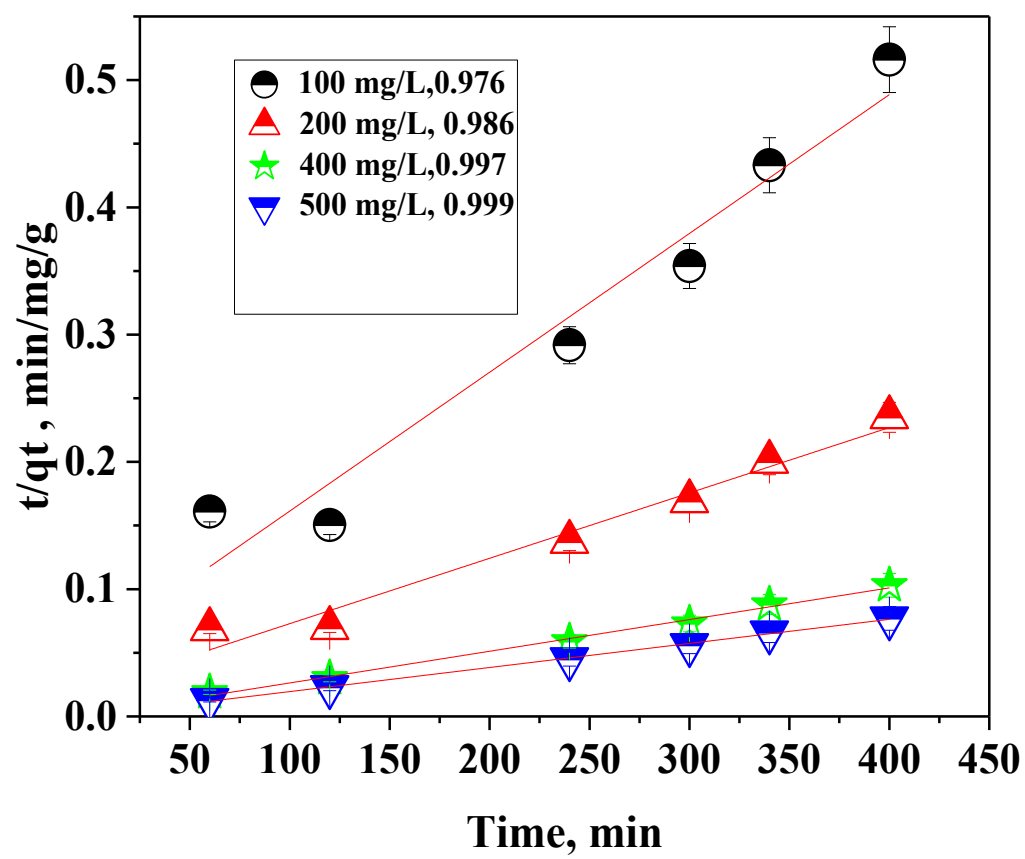


Figure 6. Pseudo-second order kinetic plots for BSA adsorption $\mathrm{Fe}_{3} \mathrm{O}_{4} \mathrm{NPs}$.

Table 3: Kinetic parameters for adsorption of BSA onto $\mathrm{Fe}_{3} \mathrm{O}_{4}$ NPs for different initial BSA concentrations.

\begin{tabular}{|c|c|c|c|c|c|c|}
\hline \multirow{2}{*}{$\begin{array}{l}\text { Concentration } \\
\mathrm{BSA}, \mathrm{mgL}^{-1}\end{array}$} & \multicolumn{3}{|c|}{ Pseudo-second-order } & \multicolumn{3}{|c|}{ pseudo-first-order } \\
\hline & $\mathrm{K}_{2}$ & $\mathrm{q}_{\mathrm{e}}, \mathrm{mg} \cdot \mathrm{g}^{-1}$ & $\mathrm{R}^{2}$ & $\mathrm{~K}_{1}$ & $\mathrm{q}_{\mathrm{e}}, \mathrm{mg} \cdot \mathrm{g}^{-1}$ & $\mathrm{R}^{2}$ \\
\hline 100 & 0.0524 & 0.0011 & 0.953 & 0.0184 & 4.617 & 0.941 \\
\hline 200 & 0.0215 & 0.0005 & 0.972 & 0.007 & 3.096 & 0.781 \\
\hline 400 & 0.0019 & 0.0002 & 0.993 & 0.0009 & 3.934 & 0.779 \\
\hline 500 & 0.0007 & 0.0002 & 0.998 & 0.0004 & 1.701 & 0.727 \\
\hline
\end{tabular}

The results are shown in Figure 6 and Table 3. The $\mathrm{R}^{2}$ values of the pseudo-second-order models ranged between 0.953 and 0.998 , and as the concentration of BSA increases, the fit improves. This is considerably higher than the $\mathrm{R}^{2}$ values of the pseudo-first order model that range from 0.727 to 0.941 , where again, as the concentration rises, the fit improves. This concentration dependence suggests that slowed diffusion rates, aggregation, or other factors might be partially segregating the BSA at lower concentrations diverting the process from a pseudo-second order ideal. These effects become less important as the excess amount of BSA increases. This pseudo-second order kinetic profile is consistent with the BSA absorption studies of others who have used other classes of particles, including graphene materials and $\kappa$-carrageenan/carboxymethyl chitosan-coated materials. $^{27,44}$ These results suggest that BSA-BSA interactions on the nanoparticle surface are important for the adsorption interactions. This multilayer formation is typical for protein adsorption onto a surface: at lower concentrations of protein a monolayer forms, but as concentration increases, a multilayer forms and entropically-driven adsorption can be facilitated by the presence of the previous layer. ${ }^{45,46}$

3.4.5. Adsorption thermodynamic studies: Temperature dependence provides insight into the thermodynamics of the process, allowing for the determination of parameters such as $\Delta \mathrm{G}^{0}, \Delta \mathrm{H}^{\mathrm{o}}$ and $\Delta \mathrm{S}^{\mathrm{o}}$. Thermodynamic parameters provide additional information regarding the energetic changes involved during process adsorption. In the present case, the effect of temperature on the BSA-magnetite adsorption process was studied over physiologically-relevant temperatures (298$318 \mathrm{~K})$. Plotting the observed value of $\ln \left(\mathrm{K}_{\mathrm{eq}}\right)$ against $1 / \mathrm{T}$ allows for the extraction of both $\Delta \mathrm{H}^{0}$ and $\Delta \mathrm{S}^{0}$ from the slope and intercept respectively (Figure 7). 


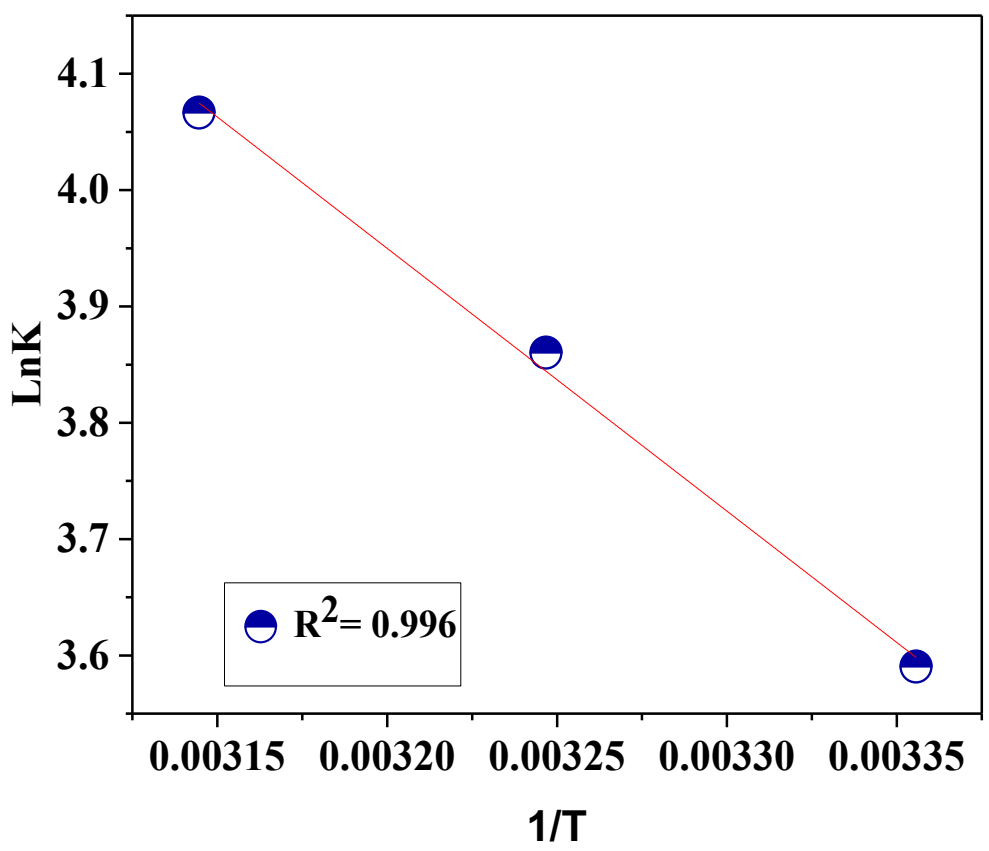

Figure 7. The natural logarithms of the adsorption equilibrium constant of BSA by $\mathrm{Fe}_{3} \mathrm{O}_{4} \mathrm{NPs}$ surfaces as a function of inverse temperature $\left(\mathrm{K}^{-1}\right)$ for the calculation of thermodynamic parameters. Error represents the standard error of the mean of three measurements.

Table 4. Thermodynamic parameters for the adsorption of BSA on the surface of synthesized $\mathrm{Fe}_{3} \mathrm{O}_{4} \mathrm{NPs}$ determined using an initial concentration of $500 \mathrm{mg} / \mathrm{L}$ of BSA and $0.8 \mathrm{mg} / \mathrm{L}$ of magnetite nanoparticle.

\begin{tabular}{|c|c|c|c|c|}
\hline $\mathrm{T}(\mathrm{K})$ & $\mathrm{K}_{\mathrm{e}}(\mathrm{L} / \mathrm{g})$ & $\Delta \mathrm{G}^{\circ}(\mathrm{kJ} / \mathrm{mol})$ & $\Delta \mathrm{H}^{\circ}(\mathrm{kJ} / \mathrm{mol})$ & $\Delta \mathrm{S}^{\circ}\left(\mathrm{J} \cdot \mathrm{mol}^{-1} \cdot \mathrm{K}^{-1}\right)$ \\
\hline 298 & 36.25 & -8.90 & & \\
\hline 308 & 47.48 & -9.89 & 18.73 & 92.8 \\
\hline 318 & 58.36 & -10.75 & & \\
\hline
\end{tabular}

The moderate negative values of $\Delta \mathrm{G}^{0}(-8.9$ to $-10.8 \mathrm{~kJ} / \mathrm{mol})$ indicate that the reaction is spontaneous at all temperatures and is due to a physisorption process rather than any chemisorption (where we would expect values in excess of $80 \mathrm{~kJ} / \mathrm{mol}$ ). ${ }^{27}$ The moderate positive enthalpies support this contention, and the positive entropy suggests that the system is becoming increasingly disordered, potentially due to the multiple different conformations and distortions to the preferred solvated structure that can occur on the surface of the nanoparticle. This is in contrast to other systems where the adsorption process is strongly entropically disfavoured although enthalpically favoured, allowing for a spontaneous process. ${ }^{27,} 39$ However, another report showed that a differentially-coated magnetite, using carboxymethyl chitosan, was enthalpically disfavoured 
while being entropically favoured like this current example, ${ }^{47}$ and this has been observed for other surfaces as well, including $\mathrm{CoCrMo},{ }^{48}$ and silica ${ }^{49}$ Entropically driven protein adsorption is largely driven by the desolvation of the protein and nanoparticle..$^{50}$ The more hydrophobic the surface, the better the benefit of desolvation and the more unlikely an enthalpically favourable interaction drives protein adsorption. ${ }^{45}$ Adsorption can also increase the conformational flexibility of the protein further increasing the entropy of the system, and BSA denaturation on particle surfaces is an ongoing field of study.

Together, these studies lead to interesting results. Protein-corona formation is generally considered an extremely rapid process, on the order of seconds. ${ }^{5}$ However, in this case, the particles continue to adsorb additional BSA well into the second hour of exposure, this is perhaps explained by the multilayer that forms around the nanoparticle.

A corona almost certainly forms immediately, but does not assume an equilibrium form for up to two hours. The DLS studies indicate that this is not due to a nanoparticle aggregation effect, as there is no indication of aggregate formation. Potentially the formation of the corona keeps the reactive nanoparticle surface away from mammalian cells, slowing oxidative-related toxicity, while the internal chemistry of bacteria might change this corona sufficiently that the surface can be cytotoxic. This study demonstrates that a normal corona is formed around these particles, and that their remarkable antibiotic activity may be due to the differential response of mammalian and bacterial systems to this corona.

\section{Conclusion}

Our previously prepared and characterized nanoparticles showed remarkable antibiotic activity. This was attributed to the highly oxidized impurities on their surface which also prevented aggregation. Curiously, the particles showed no toxicity against mammalian tissue. This work investigated the formation of a protein corona around these nanoparticles using BSA as the model protein. These nanoparticles show exceptional affinity for BSA with very high loading efficiencies up to $5 \mathrm{~g}$ protein $/ \mathrm{g}$ of nanoparticle. Formation of the protein corona results in a moderate increase in size of the nanoparticles and does not induce aggregation as measured by DLS. The adsorption of the BSA onto these uncoated magnetite nanoparticles is best modelled using a Langmuir Type (II) isotherm $\left(\mathrm{R}^{2}=0.991\right)$ under a pseudo-second order kinetic model $\left(\mathrm{R}^{2}=0.998\right)$. These suggest that BSA binds in a multilayered fashion to the surface of the particles, and that BSA-BSA interactions are stronger than BSA-magnetite interactions. Calculations of the thermodynamic parameters indicate that adsorption at ambient temperature and pressure is a spontaneous entropically-driven process, and the moderate Gibbs free energies unsurprisingly indicate a physical adsorption process. These results show that protein corona formation around these particles, although favourable, is not strongly so, and consequently this might provide some explanation for the remarkable observed biological activity. Further preclinical investigations of the antibiotic potential of these materials are currently underway in our labs and results will be released in due course.

\section{Acknowledgements}


The Authors would like to thank the University of Zabol and the Zabol University of Medical Sciences for financial support for this work. This work was also funded by the Natural Sciences and Engineering Research Council of Canada grant \# 2018-06338 to JFT.

1. Francis, G. L., Albumin and mammalian cell culture: Implications for biotechnology applications. Cytotechnology 2010, 62 (1), 1-16. http://doi.org/10.1007/s10616-010-9263-3.

2. Fanali, G.; di Masi, A.; Trezza, V.; Marino, M.; Fasano, M.; Ascenzi, P., Human serum albumin: From bench to bedside. Mol. Aspects Med. 2012, 33 (3), 209-290.

http://doi.org/10.1016/i.mam.2011.12.002.

3. Elsadek, B.; Kratz, F., Impact of albumin on drug delivery - New applications on the horizon. $J$. Controlled Release 2012, 157 (1), 4-28. http://doi.org/10.1016/i.jconrel.2011.09.069.

4. Majorek, K. A.; Porebski, P. J.; Dayal, A.; Zimmerman, M. D.; Jablonska, K.; Stewart, A. J.; Chruszcz, M.; Minor, W., Structural and immunologic characterization of bovine, horse, and rabbit serum albumins. Molecular Immunology 2012, 52 (3), 174-182. http://doi.org/10.1016/i.molimm.2012.05.011.

5. Tenzer, S.; Docter, D.; Kuharev, J.; Musyanovych, A.; Fetz, V.; Hecht, R.; Schlenk, F.; Fischer, D.; Kiouptsi, K.; Reinhardt, C.; Landfester, K.; Schild, H.; Maskos, M.; Knauer, S. K.; Stauber, R. H., Rapid formation of plasma protein corona critically affects nanoparticle pathophysiology. Nat. Nanotechnol. 2013, 8 (10), 772-781. http://doi.org/10.1038/nnano.2013.181.

6. Marchesan, S.; Melchionna, M.; Prato, M., Carbon nanostructures for nanomedicine: Opportunities and challenges. Fullerenes, Nanotubes, Carbon Nanostruct. 2014, 22 (1-3), 190-195. http://dx.doi.org/10.1080/1536383x.2013.798726.

7. Laurent, S.; Saei, A. A.; Behzadi, S.; Panahifar, A.; Mahmoudi, M., Superparamagnetic iron oxide nanoparticles for delivery of therapeutic agents: Opportunities and challenges. Expert Opin. Drug Delivery 2014, 11, 1449-1470. http://doi.org/10.1517/17425247.2014.924501.

8. Rial, R.; Tichnell, B.; Latimer, B.; Liu, Z.; Messina, P. V.; Ruso, J. M., Structural and kinetic visualization of the protein corona on bioceramic nanoparticles. Langmuir 2018, 34 (7), 2471-2480. http://doi.org/10.1021/acs.langmuir.7b03573.

9. Chen, J.; Wang, Y.; Ding, X.; Huang, Y.; Xu, K., Magnetic solid-phase extraction of proteins based on hydroxy functional ionic liquid-modified magnetic nanoparticles. Anal. Methods 2014, 6 (20), 8358-8367. http://doi.org/10.1039/c4ay01786b.

10. Salloum, D. S.; Schlenoff, J. B., Protein adsorption modalities on polyelectrolyte multilayers. Biomacromolecules 2004, 5 (3), 1089-1096. http://doi.org/10.1021/bm034522t.

11. Swain, S. K.; Sarkar, D., Study of BSA protein adsorption/release on hydroxyapatite nanoparticles. Appl. Surf. Sci. 2013, 286, 99-103. http://doi.org/10.1016/i.apsusc.2013.09.027.

12. Chaudhary, A.; Gupta, A.; Khan, S.; Nandi, C. K., Morphological effect of gold nanoparticles on the adsorption of bovine serum albumin. Phys. Chem. Chem. Phys. 2014, 16 (38), 20471-20482. http://doi.org/10.1039/c4cp01515k.

13. Song, M.-M.; Branford-White, C.; Nie, H.-L.; Zhu, L.-M., Optimization of adsorption conditions of BSA on thermosensitive magnetic composite particles using response surface methodology. Colloids Surf., B: Biointerf. 2011, 84 (2), 477-483. http://doi.org/10.1016/i.colsurfb.2011.02.002.

14. Wei, H.; Yang, W.; Xi, Q.; Chen, X., Preparation of Fe3O4@graphene oxide core-shell magnetic particles for use in protein adsorption. Mater. Lett. 2012, 82, 224-226. http://doi.org/10.1016/i.matlet.2012.05.086.

15. Xu, Z.; Grassian, V. H., Bovine serum albumin adsorption on $\mathrm{TiO}_{2}$ nanoparticle surfaces: Effects of $\mathrm{pH}$ and coadsorption of phosphate on protein-surface interactions and protein structure. J. Phys. Chem. C 2017, 121 (39), 21763-21771. http://doi.org/10.1021/acs.jpcc.7b07525.

16. Keshavarz, M.; Ghasemi, Z., Coating of iron oxide nanoparticles with human and bovine serum albumins: A thermodynamic approach. J. Phys. Theoret. Chem. 2011, 8 (2), 7-17. None assigned. 
17. Zhang, B.; Zhang, H.; Li, X.; Lei, X.; Li, C.; Yin, D.; Fan, X.; Zhang, Q., Synthesis of BSA/Fe3O4 magnetic composite microspheres for adsorption of antibiotics. Mater. Sci. Eng. C 2013, 33 (7), 44014408. http://doi.org/10.1016/i.msec.2013.06.038.

18. Peng, Z. G.; Hidajat, K.; Uddin, M. S., Adsorption of bovine serum albumin on nanosized magnetic particles. J. Colloid Interface Sci. 2004, 271 (2), 277-283.

http://doi.org/10.1016/i.jcis.2003.12.022.

19. Tang, S. C. N.; Lo, I. M. C., Magnetic nanoparticles: Essential factors for sustainable environmental applications. Water Res. 2013, 47, 2613-2632.

http://doi.org/10.1016/i.watres.2013.02.039.

20. $\quad$ Parkinson, G. S., Iron oxide surfaces. Surf. Sci. Rep. 2016, 71 (1), 272-365.

http://dx.doi.org/10.1016/j.surfrep.2016.02.001.

21. Su, C., Environmental implications and applications of engineered nanoscale magnetite and its hybrid nanocomposites: A review of recent literature. J. Hazard. Mater. 2016, 322 (Part A), 48-84. 10.1016/j.jhazmat.2016.06.060.

22. Yang, Q.; Liang, J.; Han, H., Probing the interaction of magnetic iron oxide nanoparticles with bovine serum albumin by spectroscopic techniques. J. Phys. Chem. B 2009, 113 (30), 10454-10458. http://doi.org/10.1021/jp904004w.

23. Mu, Q.; Li, Z.; Li, X.; Mishra, S. R.; Zhang, B.; Si, Z.; Yang, L.; Jiang, W.; Yan, B., Characterization of protein clusters of diverse magnetic nanoparticles and their dynamic interactions with human cells. J. Phys. Chem. C 2009, 113 (14), 5390-5395. http://doi.org/10.1021/jp809493t.

24. McClellan, S. J.; Franses, E. I., Effect of concentration and denaturation on adsorption and surface tension of bovine serum albumin. Colloids Surf., B: Biointerf. 2003, 28 (1), 63-75. http://doi.org/10.1016/S0927-7765(02)00131-5.

25. Csach, K.; Jurikova, A.; Miskuf, J.; Koneracka, M.; Zavisova, V.; Kubovcikova, M.; Kopcansky, P., Thermogravimetric study of the decomposition of BSA-coated magnetic nanoparticles. Acta Phys. Pol., A 2012, 121 (5-6), 1293-1295. http://doi.org/10.12693/APhysPolA.121.1293.

26. Li, Z.; Qiang, L.; Zhong, S.; Wang, H.; Cui, X., Synthesis and characterization of monodisperse magnetic Fe304@BSA core-shell nanoparticles. Colloids Surf., A 2013, 436, 1145-1151.

http://doi.org/10.1016/i.colsurfa.2013.08.044.

27. Mahdavinia, G. R.; Etemadi, H., Surface modification of iron oxide nanoparticles with kcarrageenan/carboxymethyl chitosan for effective adsorption of bovine serum albumin. Arabian J. Chem. 2015. http://doi.org/10.1016/j.arabjc.2015.12.002.

28. Aliahmad, M.; Rahdar, A.; Sadeghfar, F.; Bagheri, S.; Hajinezhad, M. R., Synthesis and biochemical effects of magnetite nanoparticle by surfactant-free electrochemical method in an aqueous system:the current density effect. Nanomed. Res. J. 2016, 1 (1), 39-46.

http://doi.org/10.7508/nmri.2016.01.006.

29. Taimoory, S. M.; Rahdar, A.; Aliahmad, M.; Sadeghfar, F.; Hashemzaei, M.; Trant, J. F., Importance of the inter-electrode distance for the electrochemical synthesis of magnetite nanoparticles: Synthesis, characterization, and cytotoxicity. e-Journal of Surface Science and Nanotechnology 2017, 15, 31-39. http://doi.org/10.1380/ejssnt.2017.31.

30. Taimoory, S. M.; Rahdar, A.; Aliahmad, M.; Sadeghfar, F.; Hajinezhad, M. R.; Jahantigh, M.; Shahbazi, P.; Trant, J. F., The synthesis and characterization of a magnetite nanoparticle with potent antibacterial activity and low mammalian toxicity. Journal of Molecular Liquids 2018, 265, 96-104. http://doi.org/10.1016/j.molliq.2018.05.105.

31. Jiang, W.; Yang, H. C.; Yang, S. Y.; Horng, H. E.; Hung, J. C.; Chen, Y. C.; Hong, C.-Y., Preparation and properties of superparamagnetic nanoparticles with narrow size distribution and biocompatible. $J$. Magn. Magn. Mater. 2004, 283 (2), 210-214. http://doi.org/10.1016/i.jmmm.2004.05.022. 
32. Albanese, A.; Tang, P. S.; Chan, W. C. W., The effect of nanoparticle size, shape, and surface chemistry on biological systems. Ann. Rev. Biomed. Eng. 2012, 14 (1), 1-16.

http://doi.org/10.1146/annurev-bioeng-071811-150124.

33. Park, S. I.; Lim, J. H.; Kim, J. H.; Yun, H. I.; Roh, J. S.; Kim, C. G.; Kim, C. O., Effects of surfactant on properties of magnetic fluids for biomedical application. Phys. Status Solidi B 2004, 241, 1662-1664. http://doi.org/10.1002/pssb.200304692.

34. Ayranci, E.; Duman, O., Structural effects on the interactions of benzene and naphthalene sulfonates with activated carbon cloth during adsorption from aqueous solutions. Chem. Eng. J. (Amsterdam, Neth.) 2010, 156 (1), 70-76. http://doi.org/10.1016/i.cej.2009.09.038.

35. Rahdar, A.; Almasi-Kashi, M.; Mohamed, N., Light scattering and optic studies of Rhodamine Bcomprising cylindrical-like AOT reversed micelles. Journal of Molecular Liquids 2016, 223, 1264-1269. http://doi.org/10.1016/i.molliq.2016.09.058.

36. Mahmoudi, M.; Lynch, I.; Ejtehadi, M. R.; Monopoli, M. P.; Bombelli, F. B.; Laurent, S., Protein-nanoparticle interactions: Opportunities and challenges. Chem. Rev. 2011, 111 (9), 5610-5637. http://doi.org/10.1021/cr100440g.

37. Wright, A. K.; Thompson, M. R., Hydrodynamic structure of bovine serum albumin determined by transient electric birefringence. Biophys. J. 1975, 15 (2, Part 1), 137-141.

http://doi.org/10.1016/S0006-3495(75)85797-3.

38. Kopac, T.; Bozgeyik, K., Effect of surface area enhancement on the adsorption of bovine serum albumin onto titanium dioxide. Colloids Surf., B 2010, 76 (1), 265-271.

http://doi.org/10.1016/i.colsurfb.2009.11.002.

39. Maleki, M. S.; Moradi, O.; Tahmasebi, S., Adsorption of albumin by gold nanoparticles:

Equilibrium and thermodynamics studies. Arabian J. Chem. 2017, 10, S491-S502.

http://doi.org/10.1016/i.arabjc.2012.10.009.

40. Bazrafshan, E.; Kord Mostafapour, F.; Rahdar, S.; Mahvi, A. H., Equilibrium and thermodynamics studies for decolorization of Reactive Black 5 (RB5) by adsorption onto MWCNTs. Desalin. Water Treat. 2015, 54 (8), 2241-2251. http://doi.org/10.1080/19443994.2014.895778.

41. Foo, K. Y.; Hameed, B. H., Insights into the modeling of adsorption isotherm systems. Chem. Eng. J. (Amsterdam, Neth.) 2010, 156 (1), 2-10. http://doi.org/10.1016/j.cej.2009.09.013.

42. Bazrafshan, E.; Rahdar, S.; Balarak, D.; Mostafapour, F. K.; Zazouli, M. A., Equilibrium and thermodynamics studies for decolorization of reactive black 5 by adsorption onto acid modified banana leaf ash. Iranian Journal of Health Sciences 2015, 3 (3), 15-28. http://doi.org/10.7508/ijhs.2015.03.003.

43. Brewer, S. H.; Glomm, W. R.; Johnson, M. C.; Knag, M. K.; Franzen, S., Probing BSA binding to citrate-coated gold nanoparticles and surfaces. Langmuir 2005, 21 (20), 9303-9307. http://doi.org/10.1021/la050588t.

44. Seredych, M.; Mikhalovska, L.; Mikhalovsky, S.; Gogotsi, Y., Adsorption of bovine serum albumin on carbon-based materials. C 2018, 4 (1). http://doi.org/10.3390/c4010003.

45. Haynes, C. A.; Norde, W., Globular proteins at solid/liquid interfaces. Colloids Surf., B 1994, 2 (6), 517-566. http://doi.org/10.1016/0927-7765(94)80066-9.

46. Young, B. R.; Pitt, W. G.; Cooper, S. L., Protein adsorption on polymeric biomaterials: II. Adsorption kinetics. J. Colloid Interface Sci. 1988, 125 (1), 246-260. http://doi.org/10.1016/00219797(88)90073-2.

47. Wang, Z.; Yue, T.; Yuan, Y.; Cai, R.; Niu, C.; Guo, C., Kinetics of adsorption of bovine serum albumin on magnetic carboxymethyl chitosan nanoparticles. Int. J. Biol. Macromol. 2013, 58, 57-65. http://doi.org/10.1016/j.ijbiomac.2013.03.037.

48. Valero Vidal, C.; Olmo Juan, A.; Igual Muñoz, A., Adsorption of bovine serum albumin on CoCrMo surface: Effect of temperature and protein concentration. Colloids Surf., B 2010, 80 (1), 1-11. http://doi.org/10.1016/i.colsurfb.2010.05.005. 
49. Norde, W., Energy and entropy of protein adsorption. J. Dispersion Sci. Technol. 1992, 13 (4), 363-377. http://doi.org/10.1080/01932699208943322.

50. Serro, A. P.; Gispert, M. P.; Martins, M. C. L.; Brogueira, P.; Colaço, R.; Saramago, B., Adsorption of albumin on prosthetic materials: Implication for tribological behavior. J. Biomed. Mater. Res. A 2006, 78A (3), 581-589. http://doi.org/10.1002/jbm.a.30754.

Figure 1. FT-IR spectrum of $\mathrm{Fe}_{3} \mathrm{O}_{4}$ nanoparticles both before and after the absorption experiment.

Figure 2. The size distribution of the iron oxide nanoparticles (adsorbent dosage $0.08 \mathrm{~g} / \mathrm{L}$ ) as determined by DLS intensity measurements, both before (A) and after (B) adsorption of BSA (200 $\mathrm{mg} / \mathrm{mL}, 120 \mathrm{~min}$ incubation).

Figure 3. Percent removal and adsorption capacity of BSA (using a $200 \mathrm{mg} / \mathrm{L}$ solution) as a function of nanoparticle concentration (absorbent dose) after 120 minutes of co-incubation.

Figure 4. A) Percent sequestration of $\mathrm{BSA}$ onto $\mathrm{Fe}_{3} \mathrm{O}_{4} \mathrm{NPs}$ at an as a function of time and concentration of BSA; B) Binding efficiency of the NPs as a function of time and concentration of BSA. All measurements acquired using a nanoparticle concentration of $0.08 \mathrm{gL}^{-1}, \mathrm{~T}=298 \mathrm{~K}$, and $\mathrm{pH}=7.4$.

Figure 5. Graphical representation of the Langmuir Type (II) model of the binding of BSA onto $\mathrm{Fe}_{3} \mathrm{O}_{4} \mathrm{NPs}$ at adsorbent dosage $0.08 \mathrm{~g} / \mathrm{L}, \mathrm{T}=298 \mathrm{~K}, \mathrm{pH}=7.4$, and time $=120 \mathrm{~min}$.

Figure 6. Pseudo-second order kinetic plots for BSA adsorption $\mathrm{Fe}_{3} \mathrm{O}_{4} \mathrm{NPs}$.

Figure 7. The natural logarithms of the adsorption equilibrium constant of $\mathrm{BSA}$ by $\mathrm{Fe}_{3} \mathrm{O}_{4} \mathrm{NPs}$ surfaces as a function of inverse temperature $\left(\mathrm{K}^{-1}\right)$ for the calculation of thermodynamic parameters. Error represents the standard error of the mean of three measurements.

Table 1. The isotherm equations used in the study.

Table 2. Isotherms parameters obtained by linear regression method for the sorption of BSA by $\mathrm{Fe}_{3} \mathrm{O}_{4}$ NPs. BSA concentration $100-500 \mathrm{mg} / \mathrm{L}$, adsorbent dosage $0.08 \mathrm{~g} / \mathrm{L}$, temperature $298 \mathrm{~K}, \mathrm{pH}$ 7.4, experiments run for $120 \mathrm{~min}$.

Table 3: Kinetic parameters for adsorption of BSA onto $\mathrm{Fe}_{3} \mathrm{O}_{4} \mathrm{NPs}$ for different initial BSA concentrations.

Table 4. Thermodynamic parameters for the adsorption of BSA on the surface of synthesized $\mathrm{Fe}_{3} \mathrm{O}_{4} \mathrm{NPs}$ determined using an initial concentration of $500 \mathrm{mg} / \mathrm{L}$ of BSA and $0.8 \mathrm{mg} / \mathrm{L}$ of magnetite nanoparticle. 